\title{
Exposure to cadmium and copper triggers cytotoxic effects and epigenetic changes in human colorectal carcinoma HT-29 cells
}

\author{
ANDRADA IFTODE $^{1 *}$, GEORGE ANDREI DRĂGHICI $^{*}{ }^{*}$, IOANA MACAȘOI $^{1}$, IASMINA MARCOVICI $^{1}$, \\ DORINA E. CORICOVAC ${ }^{1}$, RAZVAN DRAGOI $^{2}$, ALINA TISCHER $^{3}$, LEDA KOVATSI $^{4}$, \\ ARISTIDIS M. TSATSAKIS ${ }^{5}$, OCTAVIAN CRETU ${ }^{3}$ and CRISTINA DEHELEAN ${ }^{1}$ \\ ${ }^{1}$ Department of Toxicology and Drug Industry, Faculty of Pharmacy, 'Victor Babes' University of Medicine \\ and Pharmacy; Departments of ${ }^{2}$ Balneology, Rehabilitation and Rheumatology, and ${ }^{3}$ Surgery I, Faculty of Medicine, \\ 'Victor Babes' University of Medicine and Pharmacy, 300041 Timisoara, Romania; ${ }^{4}$ Laboratory of Forensic Medicine \\ and Toxicology, School of Medicine, Aristotle University of Thessaloniki, 54124 Thessaloniki; ${ }^{5}$ Department of \\ Forensic Sciences and Toxicology, Faculty of Medicine, University of Crete, 71003 Heraklion, Greece
}

Received June 12, 2020; Accepted July 14, 2020

DOI: $10.3892 / \mathrm{etm} .2020 .9532$

\begin{abstract}
Recent scientific evidence suggests a link between epigenetic changes (DNA methylation) and tumorigenesis. Moreover, a potential carcinogenic mechanism of cadmium was associated with changes in DNA methylation. In this study we investigated the impact of $\mathrm{CdCl}_{2}$ and $\mathrm{CuSO}_{4}$ aqueous solutions on DNA methylation in HT-29 cells by quantifying DNA methyltransferase (DNMT1, DNMT3A and DNMT3B) mRNA expression. Furthermore, we also studied the cytotoxic
\end{abstract}

Correspondence to: Dr Dorina E. Coricovac, Department of Toxicology and Drug Industry, Faculty of Pharmacy, 'Victor Babes' University of Medicine and Pharmacy, 2 P-ta Murgu Eftimie, 300041 Timisoara, Romania

E-mail: dorinacoricovac@umft.ro

Dr Razvan Dragoi, Department of Balneology, Rehabilitation and Rheumatology, Faculty of Medicine, 'Victor Babes' University of Medicine and Pharmacy, 2 P-ta Murgu Eftimie, 300041 Timisoara, Romania

E-mail: dragoi.razvan@umft.ro

${ }^{*}$ Contributed equally

Abbreviations: AGS, gastric adenocarcinoma cell line; AsPC-1, tumor pancreatic cells; ATCC, American Type Cell Collection; Cd, Cadmium; COX-2, cyclooxygenase-2; Cu, Copper; FBS, fetal bovine serum; FLC-4, hepatoma cell line; HCT116, colon carcinoma cell line; HEK293, embryonic kidney cell line; HPNE, healthy pancreatic cells; HT-29, human colorectal carcinoma cells; IARC, International Agency for Research on Cancer; MAPK, mitogen activated protein kinase; MCF7, breast carcinoma cell line; MDA-MB468, breast carcinoma cell line; PBS, phosphate saline buffer; $\mathrm{PGE}_{2}$, prostaglandin $\mathrm{E}_{2}$; ROS, reactive oxygen species; TE4, esophageal carcinoma cell line

Key words: cadmium, copper, HT-29 cells, DNA methylation, cytotoxicity and anti-migratory potential of these substances. The results showed a dose-dependent decrease of viable cell percentage following $24 \mathrm{~h}$ of exposure (at concentrations of $0.05 ; 0.2$; $1 ; 10$ and $100 \mu \mathrm{g} / \mathrm{ml}$ ), and an inhibitory effect on HT-29 cell migration capacity. In addition, RT-qPCR results showed that cadmium acts as a hypomethylating agent by suppressing DNMT expression, whereas copper acts as a hypermethylating compound by increasing DNMT expression. These findings suggest a cytotoxic potential of both cadmium and copper on HT-29 cells and their capacity to induce epigenetic changes.

\section{Introduction}

Cadmium (Cd) is a heavy metal with a wide occurrence in the environment, classified as group 1 human carcinogen since 1993 by the International Agency for Research on Cancer (IARC) (1,2). Cadmium was described as a cumulative toxin due to its long half-life (up to 1-3 decades) and its very low rate of excretion (3), parameters that are directly linked to the noxious effects on key organs such as kidneys, liver, heart, thyroid, bones and reproductive system $(1,4-6)$. In addition, long-term exposure to $\mathrm{Cd}$ was associated with an increased risk for breast, lung, genitourinary, prostate, hepatic and colon cancer $(1,7,8)$. Although important progress has been made towards the elucidation of mechanisms involved in cadmium toxicity (such as oxidative stress, endocrine disruption, interference with sulfhydryl groups, impairment of zinc-linked cellular processes, weak mutagenicity and poor DNA binding capacity), the molecular mechanisms underlying $\mathrm{Cd}$ carcinogenic properties are not fully known and understood $(3,6,9,10)$. It was fairly recently found that $\mathrm{Cd}$ has the ability to trigger genomic instability through epigenetic mechanisms, involving DNA methylation machinery (DNMT-DNA methyltransferases) (9-12).

Colorectal cancer is the fourth cause of cancer-related mortality globally (13-15). This disease presents a heterogeneous profile characterized by chromosomal instability (most cases-over $85 \%$ ) and high-frequency microsatellite instability 
(15\% of the cases). Its occurrence is prevalent in persons with no apparent genetic predisposition or hereditary colorectal pathologies (65\%). The remaining cases are associated with familial inherited susceptibility (13). Besides the genetic risk factors, age and health status, environmental factors also play an important role in the pathogenesis of colorectal cancer (14). Previous studies supported a possible link between exposure to heavy metals such as cadmium, chromium, mercury and arsenic and the risk for colorectal cancer $(16,17)$. A recent study asserted a potential molecular mechanism for the implication of cadmium in colorectal tumor pathogenesis (1).

Copper is one of the essential metals involved in the activity of different enzymes, either as a structural component, or as a cofactor. Nevertheless, at high concentrations it is a toxic compound (18). Copper also interferes with key processes related to tumorigenesis (progression, metastasis and reluctance to conventional treatments) by direct or indirect mechanisms such as activation of the oncogenic MAPK pathway (promotion), impairment of cancer cell redox status, angiogenic activity (19), and aberrant DNA methylation and changes in expression patterns of DNMT genes $(20,21)$. Moreover, elevated copper concentrations in serum of patients represent a reliable marker for the diagnosis of a malignancy (including colorectal cancer) in advanced stage, with a low response to therapy. The link between copper and colon cancer is even stronger, since copper modulates BRAF signaling and $\mathrm{BRAF}^{\mathrm{V} 600 \mathrm{E}}$ mutation, which represents $90 \%$ of all mutations encountered in colon cancer patients $(18,19)$.

Epigenetic changes can be defined as inherited modifications in DNA with no alterations within the sequence. They include DNA methylation, miRNA regulation, and histone deacetylation (22). DNA methylation is fundamental for embryogenesis and maintenance of the specificity of cell-lineage gene expression for life (9). Dysregulated DNA methylation induces improper organism development, chronic pathologies and even tumorigenesis (9,20-22). A feature of colorectal cancer and other types of malignancies in terms of epigenetic changes, is the decreased global DNA methylation and hypermethylation of locus specific gene promoters (23-25).

In light of the data mentioned above, the present study aimed at characterizing the impact of $\mathrm{CdCl}_{2}$ and $\mathrm{CuSO}_{4}$ aqueous solutions on DNA methylation in human colorectal carcinoma HT-29 cells by quantifying DNA methyltransferase (DNMT1, DNMT3A and DNMT3B) mRNA expression. In addition, studies on cell viability and morphology, and migratory capacity were performed.

\section{Materials and methods}

Reagents. $\mathrm{CuCl}_{2}$ and $\mathrm{CuSO}_{4}$ were acquired from SigmaAldrich; Merck KGaA, as powders of analytical grade purity. The cell culture media: McCoy's 5a Medium Modified and supplements-fetal bovine serum (FBS), penicillin/streptomycin antibiotic mixture were from ATCC (American Type Cell Collection), Thermo Fisher Scientific, Inc., and Sigma-Aldrich; Merck KGaA. The other reagents used in the present experimental design: Phosphate saline buffer (PBS), Trypan blue, and Alamar blue were acquired from Sigma-Aldrich; Merck KGaA, and applied as recommended by the manufacturers.
Cell line. The in vitro experimental part of the present study was conducted on a human colorectal carcinoma cell line-HT-29 (ATCC $^{\circledR}$ HTB-38 ${ }^{\mathrm{TM}}$ ), that was acquired as frozen vial from ATCC.

Cell culture protocol. HT-29 cells were grown in specific cell culture medium, McCoy's 5a modified medium (ATCC ${ }^{\circledR}$ $30-2007^{\mathrm{TM}}$ ) supplemented with $10 \%$ fetal bovine serum (FBS) purchased from Thermo Fisher Scientific, Inc., and 1\% solution of antibiotic mixture (Penicillin and Streptomycin; Sigma-Aldrich; Merck KGaA) added to minimize the risk of contamination in the culture.

Cell viability assessment-Alamar blue test. In order to assess the impact of the test compounds $\left(\mathrm{CdCl}_{2}\right.$ and $\left.\mathrm{CuSO}_{4}\right)$ on HT-29 cell viability, the Alamar blue assay was performed. HT-29 cells were seeded in 96-well plates, $1 \times 10^{4}$ cells/well/200 $\mu \mathrm{l}$ culture medium and were allowed to adhere to the plate for $24 \mathrm{~h}$. When the cells reached the optimal confluence, the old culture medium was replaced with fresh culture medium $200 \mu \mathrm{l} /$ well that contained different concentrations of the test solutions $\left(\mathrm{CdCl}_{2}\right.$ or $\left.\mathrm{CuSO}_{4}\right)$ 0.05; 0.2; $1 ; 10$ and $100 \mu \mathrm{g} / \mathrm{ml}$ for $24 \mathrm{~h}$. The $24 \mathrm{~h}$ exposure period was followed by addition of $20 \mu \mathrm{l} /$ well of Alamar blue reagent, incubation for $3 \mathrm{~h}$ at $37^{\circ} \mathrm{C}$ and reading of the absorbance at 570 and $600 \mathrm{~nm}$ by a $\mathrm{xMark}^{\mathrm{TM}}$ Microplate spectrophotometer (Bio-rad). The percentage of viable cells (\%) was calculated according to the formula presented in a previous study (26), as follows:

Percentage of viable cells $(\%)=\left\{\left[\left(\varepsilon_{\mathrm{OX}}\right) \lambda_{2} \mathrm{~A} \lambda_{1}-\left(\varepsilon_{\mathrm{OX}}\right) \lambda_{1} \mathrm{~A} \lambda_{2}\right.\right.$ of test agent dilution $] /\left[\left(\varepsilon_{\mathrm{OX}}\right) \lambda_{2} \mathrm{~A}^{\circ} \lambda_{1}-\left(\varepsilon_{\mathrm{OX}}\right) \lambda_{1} \mathrm{~A}^{\circ} \lambda_{2}\right.$ of untreated positive growth control]\} $\mathrm{x} 100$,

Where: $\varepsilon_{\mathrm{OX}}=$ molar extinction coefficient of Alamar blue oxidized form (BLUE)

$\mathrm{A}=$ absorbance of test wells

$\mathrm{A}^{\circ}=$ absorbance of positive growth control well (cells without tested compounds)

$\lambda_{1}=570 \mathrm{~nm}$ and $\lambda_{2}=600 \mathrm{~nm}$.

Cell morphology microscopic evaluation. Changes in cell morphology and shape induced by different compounds represent specific signs of cytotoxicity. Therefore, the effect of the tested compounds on HT-29 cell morphology was evaluated as a part of the toxicological profile. The cells were photographed under bright field illumination of the Olympus IX73 inverted microscope (Olympus) at $24 \mathrm{~h}$ post-stimulation with the test compounds $\left(\mathrm{CdCl}_{2}\right.$ or $\mathrm{CuSO}_{4}, 0.05 ; 0.2 ; 1 ; 10$ and $\left.100 \mu \mathrm{g} / \mathrm{ml}\right)$ and the photos were analyzed by the cellSens Dimensions v.1.8. software (Olympus).

Migration rate evaluated by the Scratch assay. To evaluate the impact of the test compounds $\left(\mathrm{CdCl}_{2}\right.$ and $\left.\mathrm{CuSO}_{4}\right)$ on migratory capacity of HT-29 cells, the scratch assay (also known as wound healing assay) was performed. The protocol applied was similar to the one described in our previous articles $(27,28)$ and was adapted to the present experimental conditions. A number of $2 \times 10^{5} \mathrm{HT}-29$ cells/well/1.5 ml culture medium were cultured in 12-well plates. When confluence reached $90-95 \%$, the old medium was removed, a scratch was drawn manually using a pipette tip (2-200 $\mu \mathrm{l})$ and the detached cells were washed with 


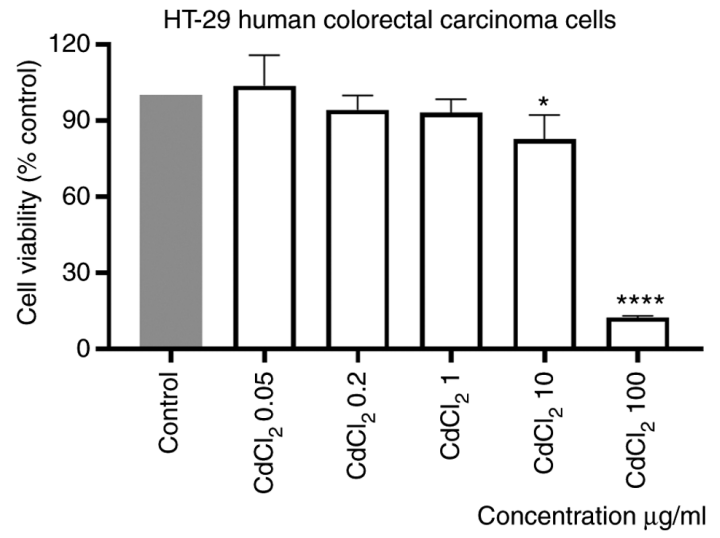

Figure 1. In vitro evaluation of the $\mathrm{CdCl}_{2}$ effect $(0.05 ; 0.2 ; 1 ; 10$ and $100 \mu \mathrm{g} / \mathrm{ml})$ on viability of HT-29 cells at $24 \mathrm{~h}$ post-stimulation by the Alamar blue assay. The results are expressed as cell viability percentage (\%) normalized to control (unstimulated) cells. The data represent the mean values \pm SD of three independent experiments performed in triplicate. One-way ANOVA analysis was applied to determine the statistical differences compared with the control group, followed by Dunnett's multiple comparisons post-test $\left({ }^{*} \mathrm{P}<0.05\right.$ and $\left.{ }^{* * * *} \mathrm{P}<0.0001\right)$.

PBS. Fresh culture medium containing the test compounds $(0.05,0.2$ and $1 \mu \mathrm{g} / \mathrm{ml})$ was added to cells for a period of $24 \mathrm{~h}$. Pictures were taken at 0 and $24 \mathrm{~h}$ following addition of the medium containing the test compounds, using an Olympus IX73 inverted microscope equipped with a DP74 camera (Olympus). The scratch widths were measured at 0 and $24 \mathrm{~h}$ by the means of CellSense Dimension 1.17. software (Olympus). The scratch closure/migration rate (\%) was calculated with the following formula:

Scratch closure $\%=\left[\left(\mathrm{A}_{\mathrm{t}=0 \mathrm{~h}} \mathrm{~A}_{\mathrm{t}=24 \mathrm{~h}}\right) / \mathrm{A}_{\mathrm{t}=0 \mathrm{~h}}\right] \mathrm{X} 100$,

Where: $A_{t=0 h}$ is the width of the wound measured immediately after scratching at $0 \mathrm{~h}$.

$A_{t=24 h}$ is the width of the wound measured after $24 \mathrm{~h}(29,30)$.

RNA extraction and reverse-transcription polymerase chain reaction (RT-PCR). Total RNA was isolated from HT-29 cells using the Trizol reagent (Thermo Fisher Scientific, Inc.) and the Quick-RNA ${ }^{\mathrm{TM}}$ purification kit (Zymo Research). cDNA was generated by reverse transcription with the Maxima ${ }^{\circledR}$ First Strand cDNA Synthesis Kit (Fermentas). Quantitative real-time PCR analysis was performed in $20 \mu 1$ reactions containing Power SYBR-Green PCR Master Mix (Thermo Fisher Scientific, Inc.)

Cycling conditions in a Quant Studio 5 real-time PCR system (Thermo Fisher Scientific, Inc.) were: $95^{\circ} \mathrm{C}$ for $10 \mathrm{sec}$ followed by 40 cycles of denaturing at $95^{\circ} \mathrm{C}$ for $15 \mathrm{sec}$ and annealing and extension at $55^{\circ} \mathrm{C}$ for $1 \mathrm{~min}$. The following primer pairs (Eurogentec) were used:

18S (as housekeeping gene): F: 5'GTAC-CCGT-TGAA-CCC C-ATT3', R: 5'CCAT-CCAA-TCGG-TAGT-AGCG3', DNMT1: F: 5'ACCG-CTTC-TACT-TCCT-CGAG-GCCTA3' R: 5'GTT G-CAGT-CCTC-GTGA-ACAC-TGTGG3'，DNMT3A: F: 5'CACA-CAGA-AGCA-TATC-CAGG-AGTG3' R: 5'AGT G-GACT-GGGA-AACC-AAAT-ACCC3', DNMT3B: F: 5'AATG-TGAA-TCCA-GTCA-GGAA-AGGC3' R: 5'ACT G-GATT-ACAC-TCCA-GGAA-CCGT3'.

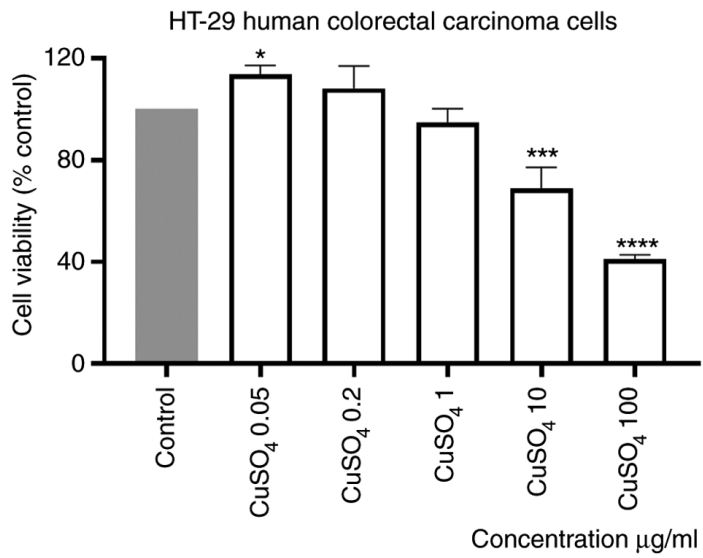

Figure 2.In vitro evaluation of the $\mathrm{CuSO}_{4}$ effect $(0.05 ; 0.2 ; 1 ; 10$ and $100 \mu \mathrm{g} / \mathrm{ml})$ on HT-29 cells viability at $24 \mathrm{~h}$ post-stimulation by the Alamar blue assay. The results are expressed as cell viability percentage (\%) normalized to control (unstimulated) cells. The data represent the mean values \pm SD of three independent experiments performed in triplicate. One-way ANOVA analysis was applied to determine the statistical differences compared with the control group, followed by Dunnett's multiple comparisons post-test $\left({ }^{*} \mathrm{P}<0.05,{ }^{* * *} \mathrm{P}<0.001\right.$ and $\left.{ }^{* * * *} \mathrm{P}<0.0001\right)$.

Statistical analysis. Graph Pad Prism 8 was used for the statistical interpretation of the data. The results were expressed as the mean \pm standard deviation (SD). One-way ANOVA was applied to determine the statistical differences followed by Dunnett's post-test $\left({ }^{*} \mathrm{P}<0.05 ;{ }^{* * * *} \mathrm{P}<0.0001\right)$.

\section{Results}

$\mathrm{CdCl}_{2}$ and $\mathrm{CuSO}_{4}$ reduced viability of $\mathrm{HT}-29$ cells in a concentration-dependent manner. The effect of $\mathrm{CdCl}_{2}$ on the viability of human colorectal HT-29 cells was evaluated after stimulation of cells with different concentrations $(0.05 ; 0.2 ; 1 ; 10$ and $100 \mu \mathrm{g} / \mathrm{ml})$ of the tested compound for $24 \mathrm{~h}$. Our results showed that the lowest concentration tested, $0.05 \mu \mathrm{g} / \mathrm{ml}$, had a stimulatory effect on cell viability. On the contrary, a dose-dependent cytotoxicity was observed when the other concentrations were tested. The effect was statistically significant only at the two highest concentrations, 10 and $100 \mu \mathrm{g} / \mathrm{ml}$, the calculated percentages of viable cells were 83 and $13 \%$, respectively (Fig. 1). The calculated $\mathrm{IC}_{50}$ value was $16.21 \mu \mathrm{g} / \mathrm{ml}$.

Stimulation of the cells with the same volume of sterile water did not influence the viability of the cells as compared with control cells (unstimulated cells).

Stimulation of HT-29 cells with a $\mathrm{CuSO}_{4}$ aqueous solution (prepared at the same concentrations as for $\mathrm{CdCl}_{2}$ ), induced a dose-dependent decrease of human colorectal carcinoma cell viability percentage, compared with control (unstimulated) cells. The effect was statistically significant only at the two highest concentrations tested, 10 and $100 \mu \mathrm{g} / \mathrm{ml}$ (Fig. 2). The calculated percentages of viable cells were 68.83 and 41.02\%, respectively. Moreover, the smallest concentrations appeared to have a stimulatory effect (Fig. 2). The $\mathrm{IC}_{50}$ value obtained was $4.4 \mu \mathrm{g} / \mathrm{ml}$.

Effect of test compounds $\left(\mathrm{CdCl}_{2}\right.$ and $\left.\mathrm{CuSO}_{4}\right)$ on morphology of HT-29 cells. As shown in Fig. 3, the solvent used for the 


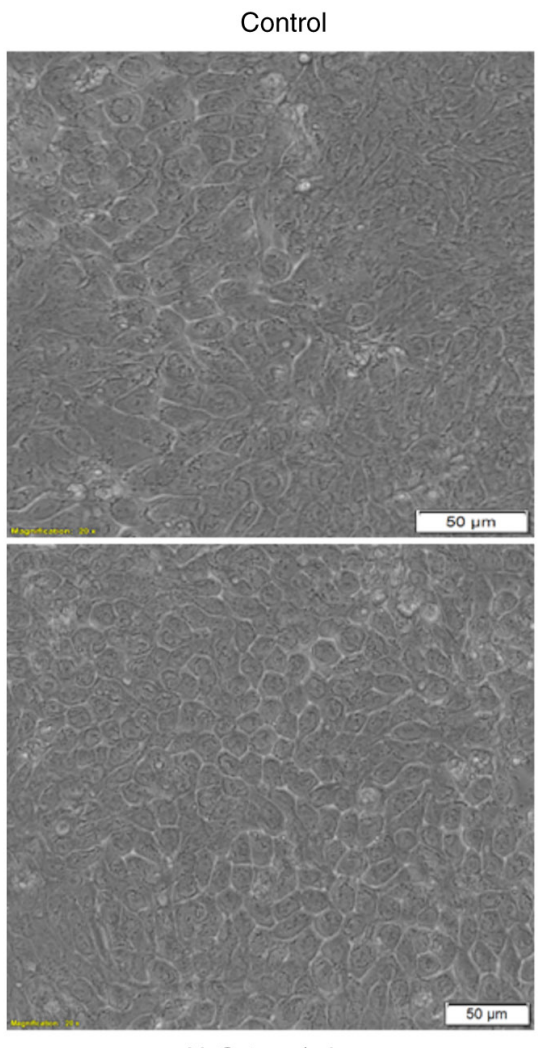

$\mathrm{H}_{2} \mathrm{O} 1 \mu \mathrm{g} / \mathrm{ml}$
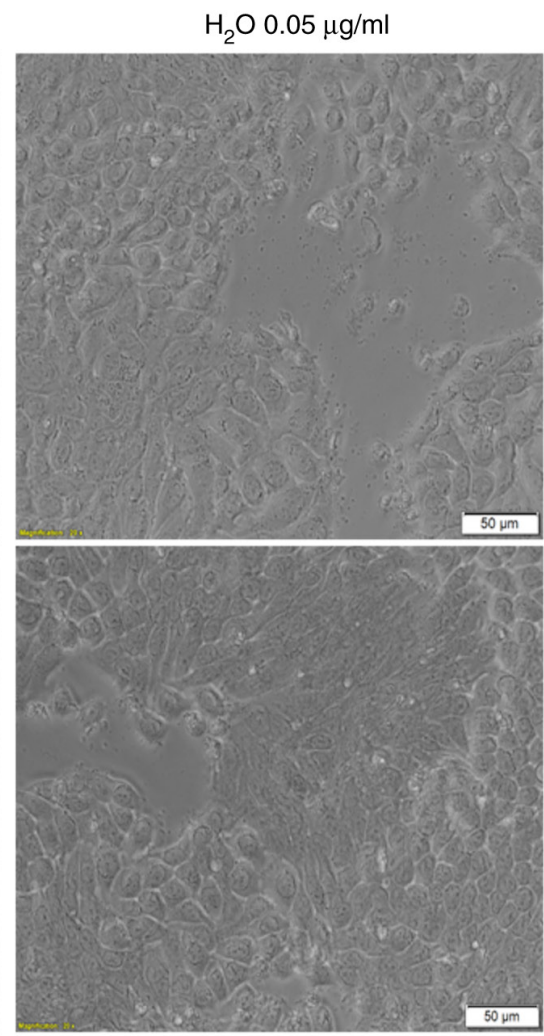

$\mathrm{H}_{2} \mathrm{O} 10 \mu \mathrm{g} / \mathrm{ml}$
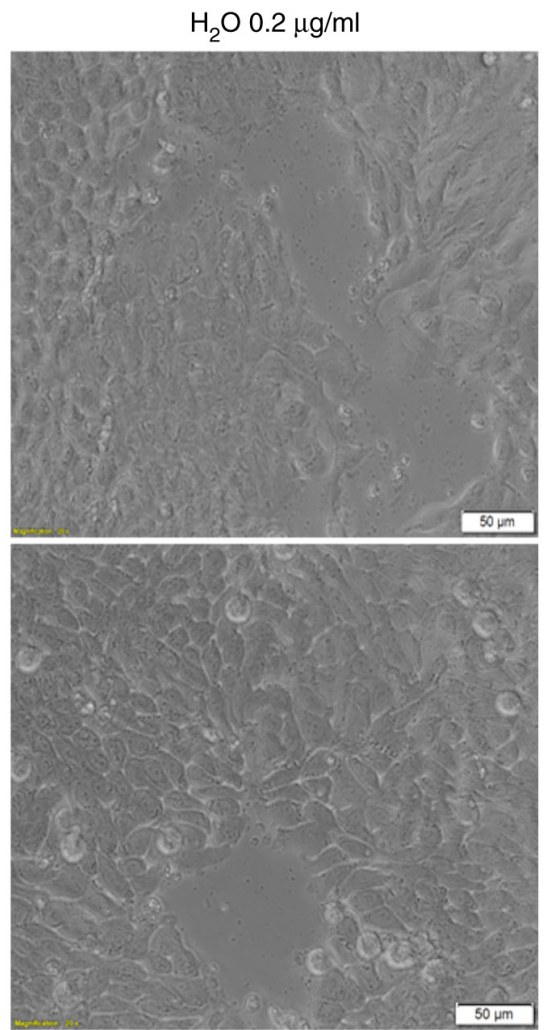

$\mathrm{H}_{2} \mathrm{O} 100 \mu \mathrm{g} / \mathrm{ml}$

Figure 3. Microscopic image of HT-29 human colorectal carcinoma cells in culture: Control cells (non-stimulated) and cells stimulated with different concentrations $(0.05 ; 0.2 ; 1 ; 10$ and $100 \mu \mathrm{g} / \mathrm{ml})$ of sterile $\mathrm{H}_{2} \mathrm{O}$ for $24 \mathrm{~h} . \mathrm{H}_{2} \mathrm{O}$ is the solvent used for the $\mathrm{CdCl}_{2}$ and $\mathrm{CuSO}_{4}$ solutions. The pictures were taken following $24 \mathrm{~h}$ of stimulation and the scale bars represent $50 \mu \mathrm{m}$.

two test solutions, sterile water, had no impact on HT-29 cell morphology as compared with control cells (unstimulated cells): The cells stimulated with sterile water present the same shape as control cells, are well-attached to the culture plate and their confluence is not affected (Fig. 3). These data are in agreement with the results obtained for viability experiments.

The addition of $\mathrm{CdCl}_{2}$ into the medium of HT-29 cells and exposure of the cells to this compound for $24 \mathrm{~h}$ was associated with several changes in cell morphology, compared with control (unstimulated) cells and solvent (sterile water) treated cells. The lowest concentrations, 0.05 and $0.2 \mu \mathrm{g} / \mathrm{ml}$ had no impact on the cell shape, confluence or adherence to the culture plate. At the concentration of $1 \mu \mathrm{g} / \mathrm{ml}$ the cells become round and were floating in the medium. At the highest concentration tested, $100 \mu \mathrm{g} / \mathrm{ml}$, the cells appeared disintegrated (Fig. 4-lower panel). These results reinforce the viability data and indicate a cytotoxic effect.

$\mathrm{CuSO}_{4}$ stimulation (at concentrations of $0.05 ; 0.2$ and $1 \mu \mathrm{g} / \mathrm{ml}$ ) for $24 \mathrm{~h}$ had no impact on HT-29 cells morphology in terms of shape, adherence or confluence as compared with control cells or solvent-stimulated cells (Fig. 5). Several changes were observed in the cells exposed to the highest concentrations of 10 and $100 \mu \mathrm{g} / \mathrm{ml}$. These cells presented different morphology related to the other groups of cells, round cells that floated (Fig. 5).

$\mathrm{CdCl}_{2}$ and $\mathrm{CuSO}_{4}$ stimulation interferes with the migratory capacity of HT-29 cells. As shown in Fig. 6, $1 \mu \mathrm{g} / \mathrm{ml}$ of $\mathrm{CdCl}_{2}$ induced a significant inhibition of cell migration following $24 \mathrm{~h}$ of exposure. Furthermore, the shape of the cells was also different (round) as compared with control cells. An inhibitory effect, less pronounced, was also recorded for the other concentrations tested (Fig. 6).

Exposure to $\mathrm{CuSO}_{4}(0.05,0.2$ and $1 \mu \mathrm{g} / \mathrm{ml})$ for $24 \mathrm{~h}$ induced a similar effect on the migratory capacity of HT-29 cells as the one described for $\mathrm{CdCl}_{2}$, namely an inhibitory effect even at the lowest concentration tested (Fig. 7).

$\mathrm{CdCl}_{2}$ and $\mathrm{CuSO}_{4}$ stimulation interferes with DNMT1, DNMT3A and DMNT3B gene expression in HT-29 human colorectal carcinoma cells

Cadmium chloride. There was a significant effect on the expression of DNMT1, DNMT3A and DNMT3B for all cadmium concentrations tested in the present experiment (ANOVA, P<0.05).

The DNMT3A expression was significantly increased at the two lowest concentrations tested, as compared with the expression of DNMT1 and DNMT3B (Newman-Keuls tests, $\mathrm{P}<0.05)$. The increase in $\mathrm{CdCl}_{2}$ concentration resulted in significant changes in the expression of DNMT1, DNMT3A and DNMT3B (ANOVA, P<0.05). Expression of DNMT1 and DNMT3B showed a similar pattern of evolution as the concentration of $\mathrm{CdCl}_{2}$ increased. The determined values decreased from the lowest cadmium concentration to the concentration of $10 \mu \mathrm{g} / \mathrm{ml}$ and increased at the concentration of $100 \mu \mathrm{g} / \mathrm{ml}$ (Table I). 


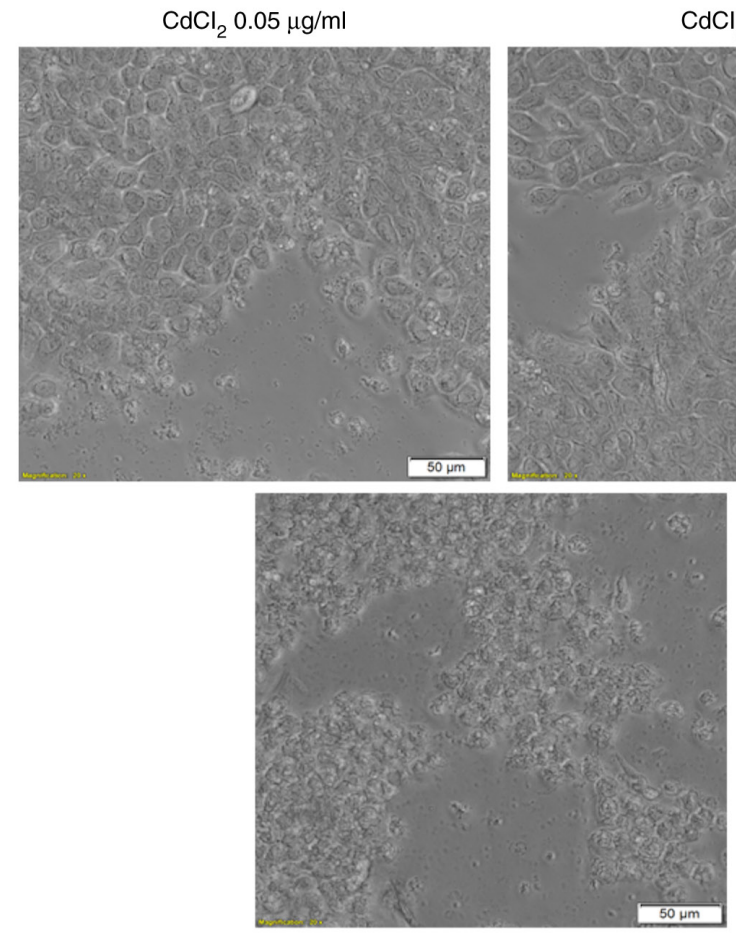

$\mathrm{CdCl}_{2} 10 \mu \mathrm{g} / \mathrm{ml}$
$\mathrm{CdCl}_{2} 0.2 \mu \mathrm{g} / \mathrm{ml}$
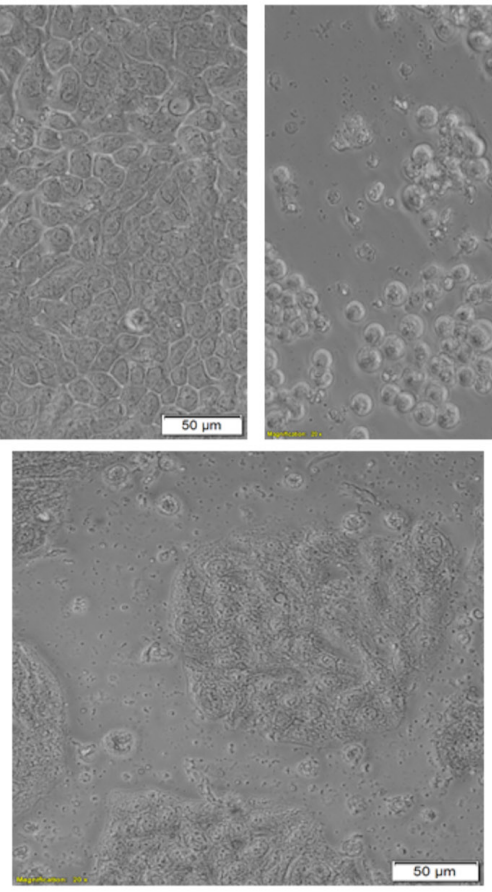

$\mathrm{CdCl}_{2} 100 \mu \mathrm{g} / \mathrm{ml}$

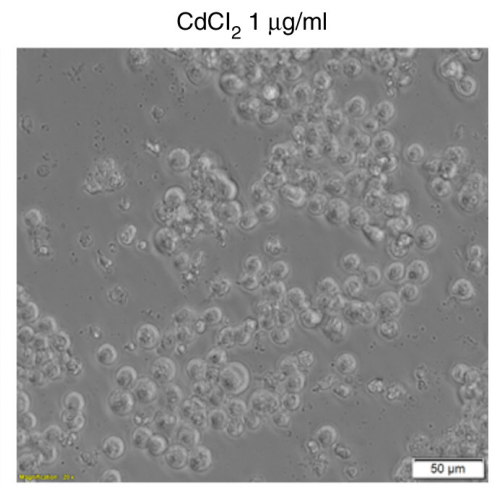

Figure 4. Microscopic appearance of HT-29 human colorectal carcinoma cells stimulated with different concentrations $(0.05 ; 0.2 ; 1 ; 10$ and $100 \mu \mathrm{g} / \mathrm{ml})$ of $\mathrm{CdCl}_{2}$ for $24 \mathrm{~h}$. The pictures were taken following $24 \mathrm{~h}$ of stimulation and the scale bars represent $50 \mu \mathrm{m}$.

$\mathrm{CuSO}_{4} 0.05 \mu \mathrm{g} / \mathrm{ml}$
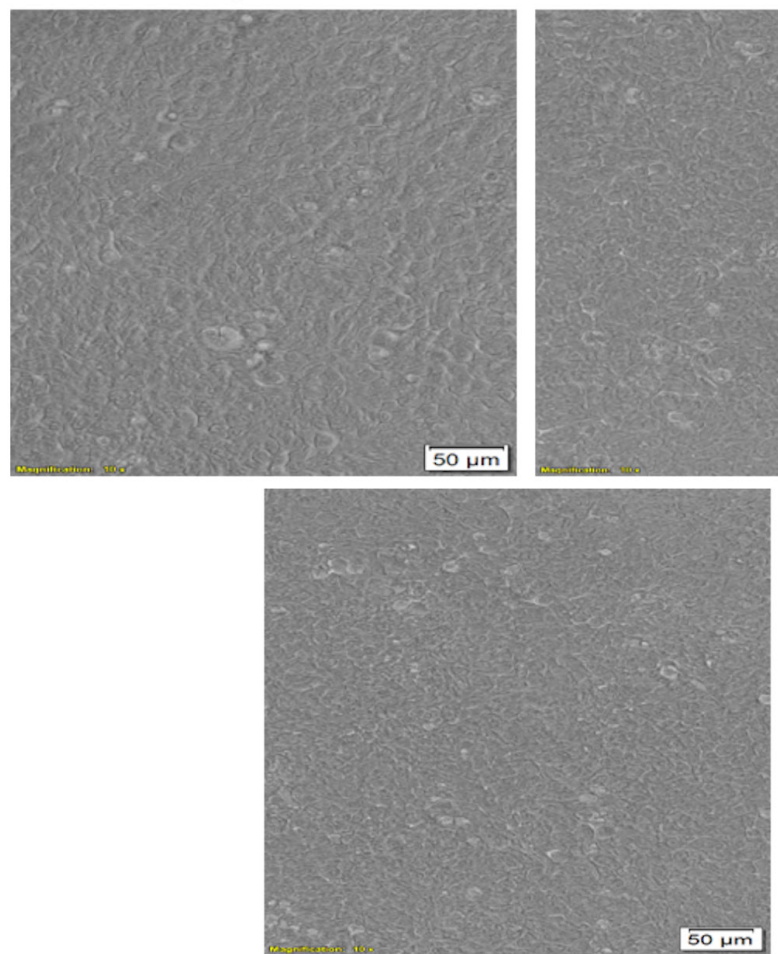

$\mathrm{CuSO}_{4} 10 \mu \mathrm{g} / \mathrm{ml}$
$\mathrm{CuSO}_{4} 0.2 \mu \mathrm{g} / \mathrm{ml}$
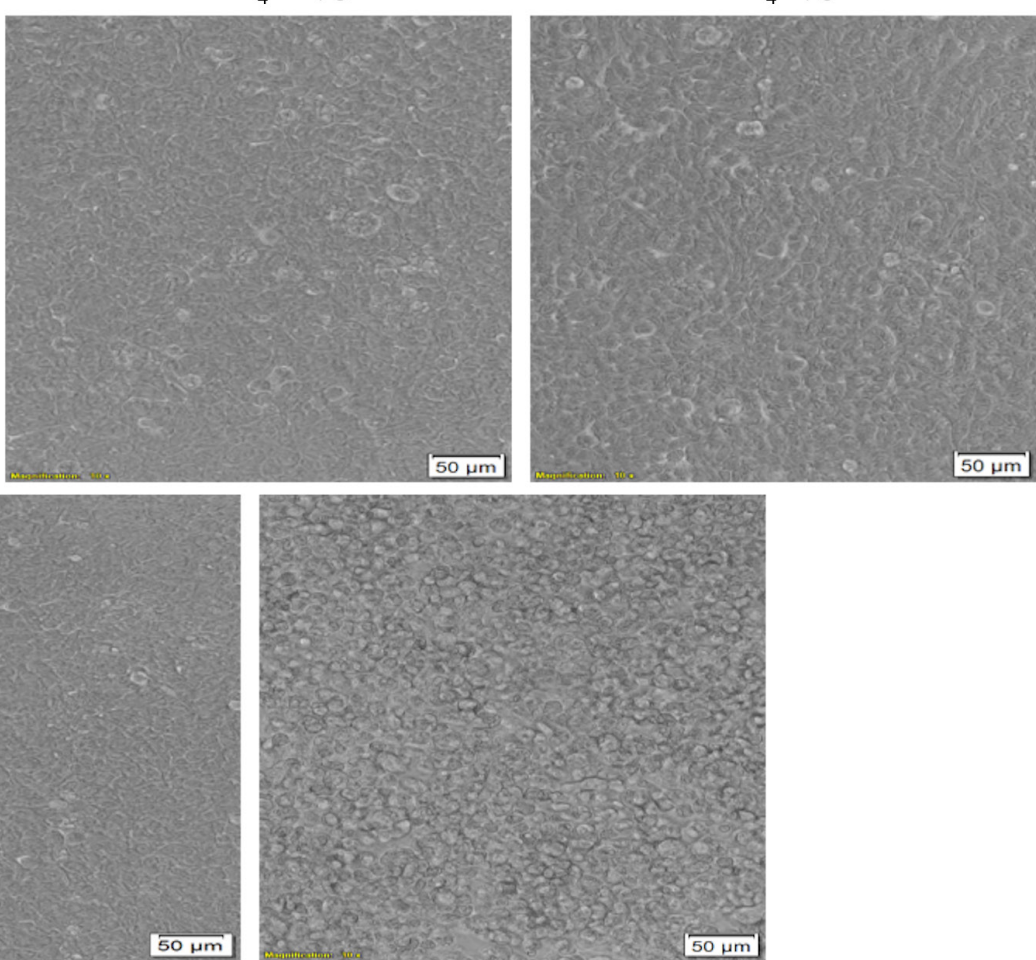

$\mathrm{CuSO}_{4} 100 \mu \mathrm{g} / \mathrm{ml}$

Figure 5. Microscopic appearance of HT-29 human colorectal carcinoma cells stimulated with different concentrations $(0.05 ; 0.2 ; 1 ; 10$ and $100 \mu \mathrm{g} / \mathrm{ml})$ of $\mathrm{CuSO}_{4}$ for $24 \mathrm{~h}$. The pictures were taken following $24 \mathrm{~h}$ of stimulation and the scale bars represent $50 \mu \mathrm{m}$.

Copper sulphate. In the case of copper, the expression of DNMT1 remained relatively constant up to the concentration of $10 \mu \mathrm{g} / \mathrm{ml}$ but showed a significant decrease for the highest dose treatment (ANOVA P $<0.05$ ). There was no detectable 
HT-29-human colorectal carcinoma cells
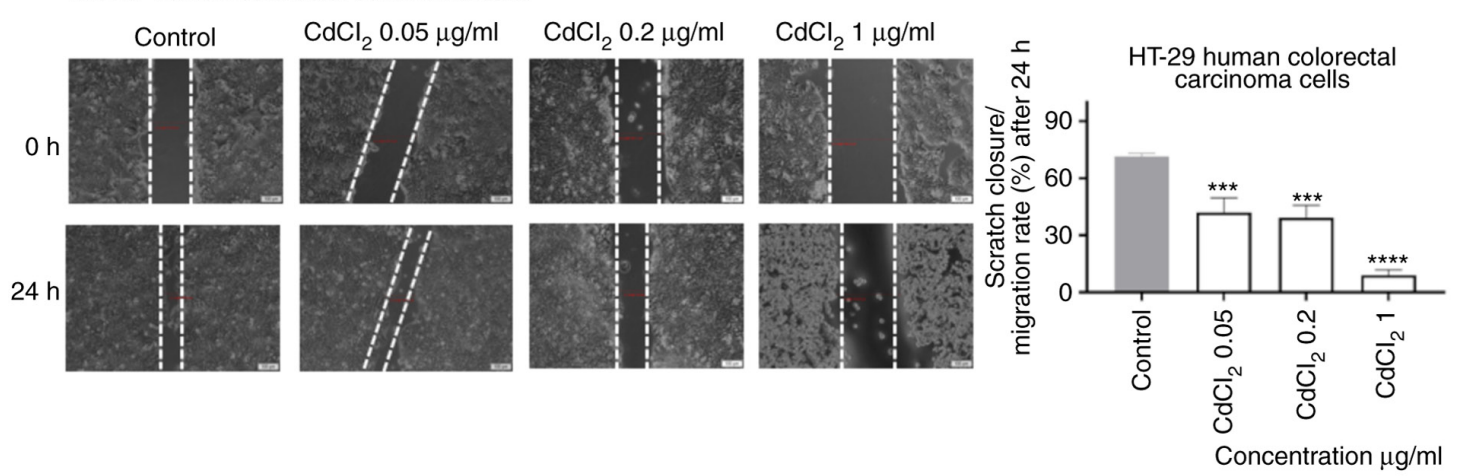

Figure 6. The impact of $\mathrm{CdCl}_{2}(0.05,0.2$ and $1 \mu \mathrm{g} / \mathrm{ml})$ on HT-29 human colorectal carcinoma cells migratory capacity following $24 \mathrm{~h}$ of stimulation. Scratch widths were initially recorded by bright field microscopy, 0 and $24 \mathrm{~h}$ post exposure, respectively. Scale bars, $100 \mu \mathrm{m}$. The results are expressed as scratch closure/migration rate (\%) following $24 \mathrm{~h}$ of stimulation. The data represent the mean values $\pm \mathrm{SD}$ of three independent experiments performed in triplicate. One-way ANOVA analysis was used to determine the statistical differences from the control cells, followed by Dunnett's multiple comparisons post-test $\left({ }^{* * * *} \mathrm{P}<0.001\right.$ and $\left.{ }^{* * * *} \mathrm{P}<0.0001\right)$.

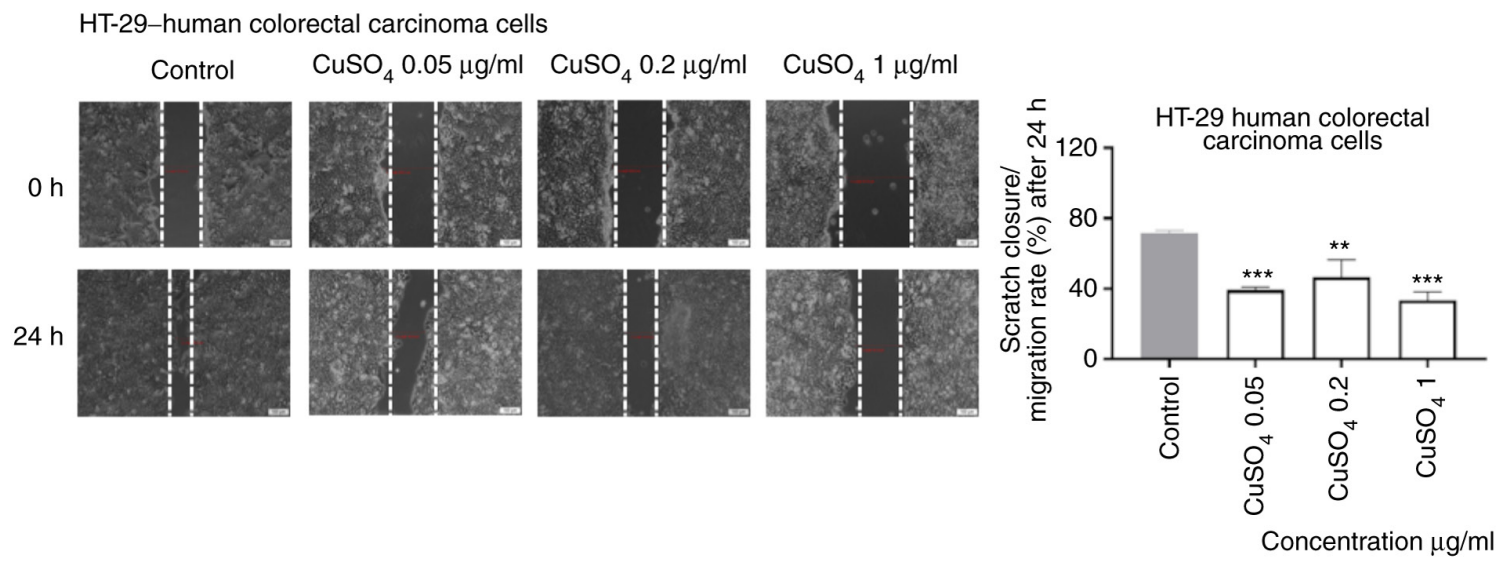

Figure 7. The impact of $\mathrm{CuSO}_{4}(0.05,0.2$ and $1 \mu \mathrm{g} / \mathrm{ml})$ on HT-29 human colorectal carcinoma cells migratory capacity following $24 \mathrm{~h}$ of stimulation. Scratch widths were initially recorded by bright field microscopy, 0 and $24 \mathrm{~h}$ post exposure. Scale bars represent $100 \mu \mathrm{m}$. The results are expressed as scratch closure/migration rate (\%) following $24 \mathrm{~h}$ of stimulation. The data represent the mean values \pm SD of three independent experiments performed in triplicate. One-way ANOVA analysis was applied to determine the statistical differences from the control cells, followed by Dunnett's multiple comparisons post-test $\left({ }^{* *} \mathrm{P}<0.01,{ }^{* * * *} \mathrm{P}<0.001\right)$.

Table I. Relative expression of DNMT1, DNMT3A and DNMT3B in human colorectal carcinoma cells (HT-29) exposed to $\mathrm{CdCl}_{2}$ and $\mathrm{CuSO}_{4}$ normalized to control (unstimulated cells).

\begin{tabular}{|c|c|c|c|c|c|c|c|c|}
\hline \multirow[b]{2}{*}{ Gene } & \multicolumn{4}{|c|}{$\mathrm{CdCl}_{2}(\mu \mathrm{g} / \mathrm{ml})$} & \multicolumn{4}{|c|}{$\mathrm{CuSO}_{4}(\mu \mathrm{g} / \mathrm{ml})$} \\
\hline & 0.05 & 1 & 10 & 100 & 0.05 & 1 & 10 & 100 \\
\hline DNMT1 & $\begin{array}{c}-3.72 \\
(-0.24)\end{array}$ & $\begin{array}{c}-5.67 \\
(-0.64)\end{array}$ & $\begin{array}{c}-8.69 \\
(-0.54)\end{array}$ & $\begin{array}{c}-1.03 \\
(-0.23)\end{array}$ & $\begin{array}{l}18.58 \\
(3.83)\end{array}$ & $\begin{array}{l}16.81 \\
(3.20)\end{array}$ & $\begin{array}{c}17.3 \\
(2.93)\end{array}$ & $\begin{array}{l}11.69 \\
(1.25)\end{array}$ \\
\hline DNMT3A & $\begin{array}{c}5.72 \\
(0.45)\end{array}$ & $\begin{array}{c}1.03 \\
(0.13)\end{array}$ & $\begin{array}{l}-17.12 \\
(-1.98)\end{array}$ & $\begin{array}{c}-7.19 \\
(-0.87)\end{array}$ & $\begin{array}{l}0 \\
-\end{array}$ & $\begin{array}{l}0 \\
-\end{array}$ & $\begin{array}{l}0 \\
-\end{array}$ & $\begin{array}{l}0 \\
-\end{array}$ \\
\hline DNMT3B & $\begin{array}{c}-2.85 \\
(-0.45)\end{array}$ & $\begin{array}{c}-5.82 \\
(-0.38)\end{array}$ & $\begin{array}{c}-13.7 \\
(-1.67)\end{array}$ & $\begin{array}{c}-8.7 \\
(-0.63)\end{array}$ & $\begin{array}{l}22.19 \\
(2.54)\end{array}$ & $\begin{array}{l}12.64 \\
(1.45)\end{array}$ & $\begin{array}{l}25.53 \\
(2.86)\end{array}$ & $\begin{array}{l}21.02 \\
(3.45)\end{array}$ \\
\hline
\end{tabular}

expression of DNMT3A. However, for DNMT3B there were significant differences (ANOVA, $\mathrm{P}<0.05$ ). The expression decreased significantly at the second lowest dose, compared with the lowest dose (Table I).

\section{Discussion}

Colorectal cancer presents lower mortality rates compared with the past, due to the efficient measures implemented 
(screening methods, early detection and intervention, optimized treatments) (14). Nevertheless, it is characterized by a poor survival rate of $13 \%$ if metastasis occurs, with an overall median survival period of 24 months $(19,31)$. Several innovative methods were developed in recent years, to gather insights into the cancer development, diagnostic, and finding novel therapeutic approaches, such as: Cellomics (32), proteomics (33), and QSAR machine learning-based models (34). The various risk factors for colorectal cancer include heredity, age, health status (different pathologies, obesity, inflammatory Bowel disease and ulcerative colitis), as well as lifestyle. Similarly, risk factors such as lifestyle (nutrition, smoking, alcohol consumption), long-term use of contraceptives, exposure to environmental toxicants were described in the tumorigenesis related to human papilloma virus infection $(35,36)$. A novel identified risk factor for colorectal cancer is microbial dysbiosis (biofilms) in gut microbiome (37), biofilms being also responsible for most types of infections ( $65 \%$ nosocomial infections and $\sim 80 \%$ of all microbial infections) (38). Furthermore, environmental toxicants such as heavy metals, including cadmium, play an asserted role in the pathogenesis of the disease, according to recent studies $(14,39)$.

The wide use of $\mathrm{Cd}$ in industry (refining industries, metal mining, construction, Cd-containing batteries, and shipyard) and its environmental dissemination $(7,40-42)$ led to the ranking of this metal among the most toxic ones (the seventh most toxic heavy metal) (16). It is responsible for multiple noxious effects such as nephrotoxicity, cardiotoxicity, bone diseases, reproductive toxicity, inflammatory disorders and tumorigenesis. To reduce the toxicity of the metals used for biomedical applications, there were proposed multiple coatings, diamond-like carbon films being a promising tool (43). The underlying molecular pathways involved in the carcinogenic properties of cadmium are not fully understood. The possible mechanisms include: i) Induction of reactive oxygen species (ROS) via activation of the mitogen activated protein kinases (MAPKs) pathway with oxidative impairment of proteins, lipids, and DNA; ii) the estrogen-like properties that were linked to the development of endometrial, breast and prostate tumors; iii) initiation of inflammation via upregulation of COX-2 (cyclooxygenase-2) expression, a key player in colorectal cancer via its major metabolite $\mathrm{PGE}_{2}$-prostaglandin $\mathrm{E}_{2}$, iv) triggering of malignant transformation in normal cells (human bronchial epithelial cells) by inducing apoptosis followed by DNA impairment, reduced DNA repair capacity and genomic instability through accumulation of mutations in DNA repair genes, creating a suitable ground for cancer development, v) epigenetic changes by interfering in DNA methylation, and vi) mitochondrial toxicity both in healthy (HPNE) and tumor (AsPC-1) pancreatic cells by altering mitochondrial function (1,2,7,9,10,44-46).

Tumor cell migration represents an essential condition for invasion and metastasis, and numerous studies have focused lately to identify the factors that regulate the migration process that is directly connected to signal biomolecules of the immune and neuroendocrine systems (47).

In a recent experimental study, Naji and colleagues showed that exposure to low levels of $\mathrm{CdCl}_{2}(100$ and $1,000 \mathrm{nM}$ equivalent to 0.01833 and $0.1833 \mu \mathrm{g} / \mathrm{ml}$, respectively) for
9 and $12 \mathrm{~h}$ induced an increased migratory effect on HT-29 cells by activating several signaling pathways, such as the ROS-p38-COX-2-PGE 2 and the ROS-Akt (1). These data are in accordance with our results that showed an increased percentage of viable cells at the lowest concentrations tested (0.05 and $0.2 \mu \mathrm{g} / \mathrm{ml})$, compared with control cells (Fig. 1). Regarding the effect of Cd on the migratory capacity of HT-29 cells in our study, the longer exposure time ( $24 \mathrm{~h})$, as compared with 9 and $12 \mathrm{~h}$ reported by Naji and colleagues, induced an inhibitory effect on HT-29 cell migration rate as compared with control cells (Fig. 6). These results are also confirmed by the study of Naji and colleagues who found that no further increase of wound closure was observed after $12 \mathrm{~h}$ (1).

An interesting finding of this work is the cytotoxic effect of $\mathrm{CdCl}_{2}$ on human colorectal carcinoma HT-29 cells which was observed at concentrations $\geq 1 \mu \mathrm{g} / \mathrm{ml}$. This effect was characterized by a decrease in the viable cell percentage (Fig. 1) and changes in cell morphology (Fig. 4).

This novel cytotoxic property of $\mathrm{Cd}$ on cancer cells was also reported by Hajrezaie et al in a study where colon cancer HT-29 cells were exposed for $72 \mathrm{~h}$ to a complex of Cd, a Schiff based complex, $\mathrm{CdCl}_{2}\left(\mathrm{C}_{14} \mathrm{H}_{21} \mathrm{~N}_{3} \mathrm{O}_{2}\right)$ that induced apoptosis via activation of mitochondrial pathway (31). Another study that supports our data on the cytotoxic effect of $\mathrm{Cd}$ on cancer cells, was published by Guo et al who showed the antiproliferative and proapoptotic effects of $\mathrm{CdCl}_{2}$ as a single agent, as well as in combination with hSmac, in hepatocellular carcinoma cells (48).

Zhou et al showed that $\mathrm{Cd}$ exerted its cytotoxic effects on multiple epithelial-like cells, both healthy, as well as of tumor origin (hepatoma cell line FLC-4, breast carcinoma MCF7, gastric adenocarcinoma AGS, colon carcinoma HCT116, esophageal carcinoma TE4 and embryonic kidney cell line HEK293) in a cell-type and dose-dependent manner (49). A dose- and time-dependent cytotoxic effect of $\mathrm{CdCl}_{2}$ was shown on MDA-MB468 breast carcinoma cells (50), data that are in agreement with our results.

The connection between colorectal cancer and copper could be considered stronger, compared with cadmium, since elevated serum concentrations of copper in patients diagnosed with colorectal cancer indicate an advanced disease with a high risk of mortality (19).

The role of copper in the modulation of tumorigenesis via direct or indirect mechanisms (angiogenic cofactor, a redox-active metal and activation of MAPK pathway) is established. Moreover, it was shown that depletion of copper determines apoptosis of cancer cells (19). To highlight the function of $\mathrm{Cu}$ in colon cancer, different copper chelators were tested as potential anticancer therapies $(18,19)$.

A strong connection also lies between $\mathrm{Cd}$ and $\mathrm{Cu}$, since $\mathrm{Cd}$ is responsible for a disrupted balance of essential metals ( $\mathrm{Zn}, \mathrm{Cu}, \mathrm{Ca}$ ) leading to depletion of these metals and inducing noxious effects on human health including cancer of the intestine (39). In our previous study, conducted on land snails-Cantareus aspersus, we showed that low doses of dietary cadmium interfere with hepatopancreas copper deposition (51).

Our results on the effect of $\mathrm{Cu}$ on $\mathrm{HT}-29$ cell viability showed a dose-dependent cytotoxic effect and are supported by the findings of another study that tested a $\mathrm{CuCl}_{2}$ solution 
(1-1,000 $\mu \mathrm{M})$ on MDA-MB458 breast carcinoma cells (50). The cytotoxic effect of a $\mathrm{CuSO}_{4}$ solution was also studied on a human glioma cell line-U87-MG (52) and HeLa cells (53). The findings of both studies are consistent with our results. Moreover, our experimental data indicate an anti-migratory effect of copper on HT-29 cells (Fig. 7).

Among the multiple mechanisms of toxicity linked to cadmium and copper exposure, the interference with DNA methylation has also been described (3,9-11,20,21). DNA methylation is prevalent in the mammalian genome and is responsible for genomic stability, chromatin structure modulation, and transcriptional regulation of specific genes $(22,25)$. This process occurs at the cytosines in specific regions of $\mathrm{CpG}$ dinucleotides and is catalyzed by DNA methyltransferases (DNMTs), DNMT1, DNMT3A and DNMT3B $(22,25,54)$. DNMT1 is responsible for maintaining the patterns of DNA methylation during cell division and shows an affinity for hemi-methylated DNA strands, whereas DNMT3A and DNMT3B are described as de novo methyltransferases with different target sites from DNMT1 $(22,25,54)$. Impaired DNA methylation has been associated with carcinogenesis (including colorectal cancer) and with the carcinogenic potential of cadmium $(3,24)$.

The expression of DNMT1 and DNMT3B, key players in establishing and maintaining the DNA methylation patterns, are known to be disrupted in the HT-29 cell line. It was found that these genes are generally silenced in different colorectal cancer cell lines, including the HT-29 cell line, and the consequent disruptions in the methylation pattern contribute directly to the process of carcinogenesis (55). Other studies indicate that DNMT1, DNMT3A and DNMT3B are highly expressed in colon cancer $(56,57)$, and the inhibition of their expression determines a reduction of tumorigenesis process (58). With respect to copper, scientific evidence on humans does not support an effect of this trace metal on genomic or gene-specific DNA methylation levels (59). However, our results show that copper has an effect on the expression of DNMT1 and DNMT3B, and subsequently on DNA methylation in the HT-29 cell line. Our data show that the expression of these genes is increased in response to copper exposure over a broad range of concentrations. This is most probably related to the dysregulated methylation control cycle in these tumor cells, which favors their uncontrolled growth and spreading (60). The relationship between the concentrations of $\mathrm{CuSO}_{4}$ and changes in the expression of the three enzymes were strikingly different; DNMT1 expression in copper exposed cells showed a significant decrease and approached the expression levels in control (unstimulated cells) only at the highest $\mathrm{CuSO}_{4}$ concentration $(100 \mu \mathrm{g} / \mathrm{ml})$. DNMT3B exhibited the same trend at a significantly lower $\mathrm{CuSO}_{4}$ concentration $(1 \mu \mathrm{g} / \mathrm{ml})$. These patterns might be related to their different role in establishing and maintaining the DNA methylation pattern.

The effect of cadmium on DNMT1 and DNMT3B expression showed a similar pattern. The expression of both enzymes was suppressed by cadmium. This finding is consistent with the results of a previous study that showed an association between acute cadmium exposure and decreased DNA methylation in the TRL1215 rat liver cells. It showed that the decrease in genomic DNA methylation levels is caused by noncompetitive inhibition of DNMT activity, a mechanism which could also explain our results (61). In this context, it is noteworthy to highlight the differential effect of $\mathrm{Cu}$ and $\mathrm{Cd}$ on these two genes in terms of direction and magnitude in the changes in DNMT1 and DNMT3B expression. Based on our results, it appears that for acute exposure $24 \mathrm{~h}$ of $\mathrm{Cu}$ increases expression and acts as a hypermethylating agent, while $\mathrm{Cd}$ suppresses expression and acts as a hypomethylating agent in the HT-29 cells.

We have currently shown that both $\mathrm{CdCl}_{2}$ and $\mathrm{CuSO}_{4}$ solutions induced cytotoxicity on HT-29 cells in a dose-dependent manner. The toxic effect included a decrease of cell viability, changes in cell morphology, and anti-migratory effects even at the lowest concentrations tested $(0.05$; 0.2 and $1 \mu \mathrm{g} / \mathrm{ml})$. Moreover, cadmium acts as a hypomethylating agent by suppressing DNMT expression, whereas, copper acts as a hypermethylating compound by increasing DNMT expression. A limitation of this study could be considered the selection of a single time point of $24 \mathrm{~h}$, but further studies are in progress to determine the mechanistic insights of a possible connection between the cytotoxic effects and the epigenetic changes observed.

\section{Acknowledgements}

The in vitro experiments were conducted within the Center of Pharmaco-toxicological evaluations from the Faculty of Pharmacy, 'Victor Babes' University of Medicine and Pharmacy (Timisoara, Romania).

\section{Funding}

The present study was supported by the Executive Agency for Higher Education, Research, Development and Innovation Funding Institution [grant no. PN-III-P1-1.1-PD-2016-1982] and the grant was awarded to DEC.

\section{Availability of data and materials}

All data generated or analyzed during the study are included in this published article.

\section{Authors' contributions}

GAD, AI, DEC, CD, AMT and OC conceived and designed the study. IoM, IaM, DEC, GAD and AT acquired the data and drafted the manuscript. DEC, GAD, RD and LK analysed the data. DEC, AT, AI and GAD wrote the manuscript. LK, AMT, OC and CD revised the manuscript. All authors read and approved the final version of the manuscript.

\section{Ethics approval and consent to participate}

Not applicable.

\section{Patient consent for publication}

Not applicable.

\section{Competing interests}

The authors declare that they have no competing interests. 


\section{References}

1. Naji S, Issa K, Eid A, Iratni R and Eid AH: Cadmium induces migration of colon cancer cells: Roles of reactive oxygen species, P38 and cyclooxygenase-2. Cell Physiol Biochem 52: 1517-1534, 2019.

2. Zhou Z, Wang C, Liu H, Huang Q, Wang M and Lei Y: Cadmium induced cell apoptosis, DNA damage, decreased DNA repair capacity, and genomic instability during malignant transformation of human bronchial epithelial cells. Int J Med Sci 10 1485-1496, 2013

3. Martinez-Zamudio R and Ha HC: Environmental epigenetics in metal exposure. Epigenetics 6: 820-827, 2011.

4. Reyes-Hinojosa D, Lozada-Pérez CA, Zamudio Cuevas Y, López-Reyes A, Martínez-Nava G, Fernández-Torres J, OlivosMeza A,Landa-Solis C, Gutiérrez-Ruiz MC, Rojas Del Castillo E and Martínez-Flores K: Toxicity of cadmium in musculoskeletal diseases. Environ Toxicol Pharmacol 72: 103219, 2019.

5. Geng HX and Wang L: Cadmium: Toxic effects on placental and embryonic development. Environ Toxicol Pharmacol 67: 102-107, 2019.

6. Buha A, Matovic V, Antonijevic B, Bulat Z, Curcic M, Renieri EA, Tsatsakis AM, Schweitzer A and Wallace D: Overview of cadmium thyroid disrupting effects and mechanisms. Int J Mol Sci 19: 1501, 2018

7. Luevano J and Damodaran C: A review of molecular events of cadmium-induced carcinogenesis. J Environ Pathol Toxicol Oncol 33: 183-194, 2014

8. Pal D, Suman S, Kolluru V, Sears S, Das TP, Alatassi H, Ankem MK, Freedman JH and Damodaran C: Inhibition of autophagy prevents cadmium-induced prostate carcinogenesis. Br J Cancer 117: 56-64, 2017.

9. Hossain MB, Vahter M, Concha G and Broberg K: Low-level environmental cadmium exposure is associated with DNA hypomethylation in Argentinean women. Environ Health Perspect 120: 879-884, 2012.

10. Zhou ZH, Lei YX and Wang CX: Analysis of aberrant methylation in DNA repair genes during malignant transformation of human bronchial epithelial cells induced by cadmium. Toxicol Sci 125: 412-417, 2012.

11. Šrut M, Drechsel V and Höckner M: Low levels of Cd induce persisting epigenetic modifications and acclimation mechanisms in the earthworm Lumbricus terrestris. PLoS One 12: e0176047, 2017.

12. Kimura T, Hosaka T, Nakanishi T and Aozasa O: Long-term cadmium exposure enhances metallothionein-1 induction after subsequent exposure to high concentrations of cadmium in P1798 mouse lymphosarcoma cells. J Toxicol Sci 44: 309-316, 2019.

13. Nguyen HT and Duong HQ: The molecular characteristics of colorectal cancer: Implications for diagnosis and therapy. Oncol Lett 16: 9-18, 2018.

14. Thanikachalam K and Khan G: Colorectal cancer and nutrition. Nutrients 11: 164, 2019.

15. Krasanakis T,NikolouzakisTK, Sgantzos M,Mariolis-Sapsakos T, Souglakos J, Spandidos DA, Tsitsimpikou C, Tsatsakis A and Tsiaoussis J: Role of anabolic agents in colorectal carcinogenesis: Myths and realities (Review). Oncol Rep 42: 2228-2244, 2019.

16. Jaishankar M, Tseten T, Anbalagan N, Mathew BB and Beeregowda KN: Toxicity, mechanism and health effects of some heavy metals. Interdiscip Toxicol 7: 60-72, 2014

17. Tchounwou PB, Yedjou CG, Patlolla AK and Sutton DJ: Heavy metals toxicity and the environment. Exp Suppl 101: 133-164, 2012.

18. Fatfat M, Merhi RA, Rahal O, Stoyanovsky DA, Zaki A, Haidar H, Kagan VE, Gali-Muhtasib H and Machaca K: Copper chelation selectively kills colon cancer cells through redox cycling and generation of reactive oxygen species. BMC Cancer 14: 527, 2014

19. Baldari S, Di Rocco G, Heffern MC, Su TA, Chang CJ and Toietta G: Effects of copper chelation on BRAFV600E positive colon carcinoma cells. Cancers (Basel) 11: 659, 2019.

20. Sun Y, Liu C, Liu Y, Hosokawa T, Saito T and Kurasaki M: Changes in the expression of epigenetic factors during copper-induced apoptosis in PC12 cells. J Environ Sci Health A Tox Hazard Subst Environ Eng 49: 1023-1028, 2014.

21. Dorts J, Falisse E, Schoofs E, Flamion E, Kestemont P and Silvestre F: DNA methyltransferases and stress-related genes expression in zebrafish larvae after exposure to heat and copper during reprogramming of DNA methylation. Sci Rep 6: 34254, 2016.
22. Wong KK, Lawrie $\mathrm{CH}$ and Green TM: Oncogenic roles and inhibitors of DNMT1, DNMT3A, and DNMT3B in acute myeloid leukaemia. Biomark Insights 14: 1177271919846454, 2019.

23. Sarabi MM and Naghibalhossaini F: Association of DNA methyltransferases expression with global and gene-specific DNA methylation in colorectal cancer cells. Cell Biochem Funct 33 427-433, 2015.

24. Wu W, Ye S, Tan W, Zhou Y and Quan J: Analysis of promoter methylation and epigenetic regulation of miR-32 in colorectal cancer cells. Exp Ther Med 17: 3209-3214, 2019.

25. Honeywell RJ, Sarkisjan D, Kristensen MH, de Klerk DJ and Peters GJ: DNA methyltransferases expression in normal tissues and various human cancer cell lines, xenografts and tumors. Nucleosides Nucleotides Nucleic Acids 37: 696-708, 2018.

26. Soica C, Oprean C, Borcan F, Danciu C, Trandafirescu C, Coricovac D, Crăiniceanu Z, Dehelean CA and Munteanu M: The synergistic biologic activity of oleanolic and ursolic acids in complex with hydroxypropyl- $\gamma$-cyclodextrin. Molecules 19: 4924-4940, 2014

27. Gheorgheosu D, Jung M,Ören B, Schmid T, Dehelean C, Muntean D and Bruene B: Betulinic acid suppresses NGAL-induced epithelial-to-mesenchymal transition in melanoma. Biol Chem 394: 773-781, 2013.

28. Coricovac D, Farcas C, Nica C, Pinzaru I, Simu S, Stoian D, Soica C, Proks M, Avram S, Navolan D, et al: Ethinylestradiol and Levonorgestrel as active agents in normal skin, and pathological conditions induced by UVB exposure: In vitro and in ovo assessments. Int J Mol Sci 19: 3600, 2018

29. Felice F, Zambito Y, Belardinelli E, Fabiano A, Santoni T and Di Stefano R: Effect of different chitosan derivatives on in vitro scratch wound assay: A comparative study. Int J Biol Macromol 76: 236-241, 2015

30. Grada A, Otero-Vinas M, Prieto-Castrillo F, Obagi Z and Falanga V: Research techniques made simple: Analysis of collective cell migration using the wound healing assay. J Invest Dermatol 137: e11-e16, 2017.

31. Hajrezaie M, Paydar M, Looi CY, Moghadamtousi SZ, Hassandarvish P, Salga MS, Karimian H, Shams K, Zahedifard M, Majid NA, et al: Apoptotic effect of novel Schiff based $\mathrm{CdCl}_{2}\left(\mathrm{C}_{14} \mathrm{H}_{21} \mathrm{~N}_{3} \mathrm{O}_{2}\right)$ complex is mediated via activation of the mitochondrial pathway in colon cancer cells. Sci Rep 5: 9097 2015.

32. Boda D: Cellomics as integrative omics for cancer. Current Proteomics 10: 237-245, 2013.

33. Ion A, Popa IM, Papagheorghe LM, Lisievici C, Lupu M, Voiculescu V, Caruntu C and Boda D: Proteomic approaches to biomarker discovery in cutaneous T-cell lymphoma. Dis Markers 2016: 9602472, 2016.

34. Ancuceanu R, Dinu M, Neaga I, Laszlo FG and Boda D: Development of QSAR machine learning-based models to forecast the effect of substances on malignant melanoma cells. Oncol Lett 17: 4188-4196, 2019.

35. Boda D, Docea AO, Calina D, Ilie MA, Caruntu C, Zurac S, Neagu M, Constantin C, Branisteanu DE, Voiculescu V, et al: Human papilloma virus: Apprehending the link with carcinogenesis and unveiling new research avenues (Review). Int J Oncol 52: 637-655, 2018.

36. Boda D, Neagu M, Constantin C, Voinescu RN, Caruntu C, Zurac S, Spandidos DA, Drakoulis N, Tsoukalas D and Tsatsakis AM: HPV strain distribution in patients with genital warts in a female population sample. Oncol Lett 12: 1779-1782, 2016.

37. Drewes JL, White JR, Dejea CM, Fathi P, Iyadorai T, Vadivelu J, Roslani AC, Wick EC, Mongodin EF, Loke MF, et al: High-resolution bacterial 16S rRNA gene profile meta-analysis and biofilm status reveal common colorectal cancer consortia. NPJ Biofilms Microbiomes 3: 34, 2017.

38. Andor B, Tucuina AAT, Berceanu-Vaduva D, Lazureanu V, Cheveresan A and Poenaru M: Antimicrobial activity and cytotoxic effect on gingival cells of silver nanoparticles obtained by biosynthesis. Rev Chim (Bucharest) 70: 781-783, 2019.

39. Klimczak M,Dziki A, Kilanowicz A, Sapota A, Duda-Szymańska J and Daragó A: Concentrations of cadmium and selected essential elements in malignant large intestine tissue. Prz Gastroenterol 11: 24-29, 2016.

40. Nedelescu M, Baconi D, Neagoe A, Iordache V, Stan M, Constantinescu P, Ciobanu AM, Vardas AI, Vinceti M and Tsatsakis AM: Environmental metal contamination and health impact assessment in two industrial regions of Romania. Sci Total Environ 580: 984-995, 2017. 
41. Renieri EA, Alegakis AK, Kiriakakis M, Vinceti M, Ozcagli E, Wilks MF and Tsatsakis $\mathrm{AM}$ : $\mathrm{Cd}, \mathrm{Pb}$ and $\mathrm{Hg}$ Biomonitoring in fish of the Mediterranean region and risk estimations on fish consumption. Toxics 2: 417-442, 2014.

42. Renieri EA, Safenkova IV, Alegakis AK, Slutskaya ES, Kokaraki V, Kentouri M, Dzantiev BD and Tsatsakis AM: Cadmium, lead and mercury in muscle tissue of gilthead seabream and seabass: Risk evaluation for consumers. Food Chem Toxicol 124: 439-449, 2019.

43. Calenic B, Greabu M, Caruntu C, Nicolescu MI, Moraru L, Surdu-Bob CC, Badulescu M, Anghel A, Logofatu C and Boda D: Oral keratinocyte stem cells behavior on diamond like carbon films. Romanian Biotechnological Lett 21: 11914-11922, 2016.

44. Nair AR, Degheselle O, Smeets K, Van Kerkhove E and Cuypers A: Cadmium-induced pathologies: Where is the oxidative balance lost (or Not)? Int J Mol Sci 14: 6116-6143, 2013.

45. Wallace DR, Spandidos DA, Tsatsakis A, Schweitzer A, Djordjevic V and Djordjevic AB: Potential interaction of cadmium chloride with pancreatic mitochondria: Implications for pancreatic cancer. Int J Mol Med 44: 145-156, 2019.

46. Yao M, Kargman S, Lam EC, Kelly CR, Zheng Y, Luk P, Kwong E, Evans JF and Wolfe MM: Inhibition of Cyclooxygenase-2 by Rofecoxib attenuates the growth and metastatic potential of colorectal carcinoma in mice. Cancer Res 63: 586-592, 2003.

47. Solomon I, Voiculescu VM, Caruntu C, Lupu M, Popa A Ilie MA, Albulescu R, Caruntu A, Tanase C, Constantin C, et al: Neuroendocrine factors and head and neck squamous cell carcinoma: An affair to remember. Dis Markers 2018: 9787831, 2018.

48. Guo C, Li Y, Zhang H, Wang Z, Jin M, Zhang L, An L, Hu G, Liu X, Liu Y, et al: Enhancement of antiproliferative and proapoptotic effects of cadmium chloride combined with hSmac in hepatocellular carcinoma cells. Chemotherapy 57: 27-34, 2011.

49. Zhou X, Koizumi Y, Zhang M, Natsui M, Koyota S, Yamada M, Kondo Y, Hamada F and Sugiyama T: Cadmium-coordinated supramolecule suppresses tumor growth of T-cell leukemia in mice. Cancer Sci 106: 635-641, 2015.

50. Panjehpour M, Taher MA and Bayesteh M: The growth inhibitory effects of cadmium and copper on the MDA-MB468 human breast cancer cells. J Res Med Sci 15: 279-286, 2010.

51. Nica DV, Draghici GA, Andrica FM, Popescu S, Coricovac DE, Dehelean CA, Gergen II, Kovatsi L, Coleman MD and Tsatsakis AM: Short-term effects of very low dose cadmium feeding on copper, manganese and iron homeostasis: A gastropod perspective. Environ Toxicol Pharmacol 65: 9-13, 2019.
52. Li Y, Hu J, Guan F, Song L, Fan R, Zhu H, Hu X, Shen E and Yang B: Copper induces cellular senescence in human glioblastoma multiforme cells through downregulation of Bmi-1. Oncol Rep 29: 1805-1810, 2013.

53. Chen SY, Liu ST, Lin WR, Lin CK and Huang SM: The mechanisms underlying the cytotoxic effects of copper via differentiated embryonic chondrocyte gene 1. Int J Mol Sci 20: 5225, 2019.

54. Fragou D, Fragou A, Kouidou S, Njau S and Kovatsi L: Epigenetic mechanisms in metal toxicity. Toxicol Mech Methods 21: 343-352, 2011.

55. Jin B, Yao B, Li JL, Fields CR, Delmas AL, Liu C and Robertson D: DNMT1 and DNMT3B modulate distinct polycomb-mediated histone modifications in colon cancer. Cancer Res 69: 7412-7421, 2009.

56. Subramaniam D, Thombre R, Dhar A and Anant S: DNA methyltransferases: A novel target for prevention and therapy. Front Oncol 4: 80, 2014.

57. Fouad MA, Salem SE, Hussein MM, Zekri ARN, Hafez HF, El Desouky ED and Shouman SA: Impact of global DNA methylation in treatment outcome of colorectal cancer patients. Front Pharmacol 9: 1173, 2018.

58. Li S, Han Z, Zhao N, Zhu B, Zhang Q, Yang X, Sheng D, Hou J, Guo S, Wei L and Zhang L: Inhibition of DNMT suppresses the stemness of colorectal cancer cells through down-regulating Wnt signaling pathway. Cell Signal 47: 79-87, 2018.

59. Ryu HW, Lee DH, Won HR, Kim KH, Seong YJ and Kwon SH: Influence of toxicologically relevant metals on human epigenetic regulation. Toxicol Res 31: 1-9, 2015.

60. Ogoshi K, Hashimoto S, Nakatani Y, Qu W, Oshima K, Tokunaga K, Sugano S, Hattori M, Morishita S and Matsushima K: Genome-wide profiling of DNA methylation in human cancer cells. Genomics 98: 280-287, 2011.

61. Takiguchi M, Achanzar WE, Qu W, Li G and Waalkes MP: Effects of cadmium on DNA-(Cytosine-5) methyltransferase activity and DNA methylation status during cadmium-induced cellular transformation. Exp Cell Res 286: 355-365, 2003.

This work is licensed under a Creative Commons Attribution-NonCommercial-NoDerivatives 4.0 International (CC BY-NC-ND 4.0) License. 